\title{
The Literary Canon in the Russian Magazine and Newspaper Cartoons of the late 19th - early 20th centuries
}

\section{Elena S. Sonina}

Saint Petersburg State University. Saint Petersburg, Russia. Email: sonina[at]mail.ru

\section{Abstract}

An enormous amount of research has been devoted to studying the Russian classics. Nevertheless, the issue of reflecting social ideas about the writers whose works were included into the Russian literary canon has been insufficiently studied, especially with regard to satirical graphics. Caricature in the legitimate press is considered to be a popular visual art, with the image of a Russian writer demonstrating the attitude of society towards his work.

The purpose of this paper is to study the frequency of the portrayals of Russian writers in the satirical graphics of the early 20th century, which are viewed as a reflection of the established (and constantly updated) literary canon of Russia. Our objectives include identifying the images of Russian writers found in the satirical graphics, comparing the visualization techniques used to portray the authors in the caricatures of the 19th and early 20th centuries, highlighting the visual motifs used to contrast the literature of the past and the contemporary magazine issues and pointing out the persistent satirical characterizations and tropes of the images of famous writers, depending on the periodical.

On the basis of a selective scan of 25 thin magazines and two newspapers published from 1877 to 1917, more than 200 caricatures and satirical cartoons were identified, including benevolent and spiteful caricatures of Alexander Pushkin, Nikolai Gogol, Nicolai Nekrasov, Leo Tolstoy, Maxim Gorky and many others. The cartoons held the readers' interest in their literary work, forming the people's attitude towards the human qualities of the writers and highlighting their personality among the rest of their peers. The prevalence of humor or satire was directly related to the historical context, either to the works of a particular writer, the editorial policy of publications or the position of a caricaturist. The cartoons of the early 20th century reflect the social atmosphere of the Silver Age: creative, critical, nervous and overthrowing the idols of the bygone eras. The article would prove useful for literary critics, historians of journalism and visual content researchers interested in the Russian pre-revolutionary press.

\section{Keywords}

Literary Canon; Russian Empire; Silver Age; Russian Writer; Russian Pre-Revolutionary Journalism; History of Image; Visual Techniques; Caricature; Cartoon

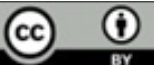

This work is licensed under a Creative Commons «Attribution» 4.0 International License 


\section{Литературный канон в русской газетно- журнальной карикатуре конца XIX - начала XX века}

\section{Сонина Елена Сергеевна}

Санкт-Петербургский государственный университет. Санкт-Петербург, Россия.

Email: sonina[at]mail.ru

\section{Аннотация}

Текстам русской классики посвящено огромное количество исследований. Тем не менее вопрос отражения общественных представлений о писателях, чьи произведения входили в русский литературный канон, изучен слабее, особенно это касается сатирической графики. Карикатура в легальной периодической печати является массовым визуальным искусством, и образ русского литератора, встречающийся в карикатуре, будет демонстрировать отношение социума к его творчеству.

Целью исследования стало изучение частотности изображений отечественных литераторов в сатирической графике начала XX века как отражения сформированного и дополняемого литературного канона России. Отсюда вытекают задачи: выявление изображений литераторов, встречающихся в сатирической графике; сопоставление приемов показа литераторов в карикатуре XIX и начала XX веков; вычленение визуальных мотивов противопоставления литературы прошлого и современности, кочующих сатирических образов, смысловых акцентов изображения крупных литературных имен в зависимости от периодического издания.

На основе выборочного просмотра 25 тонких иллюстрированных журналов и двух газет 1877-1917 годов было выявлено более 200 рисунков. Добродушные шаржи и злые карикатуры на А.С Пушкина, Н.В. Гоголя, Н.А. Некрасова, Л.Н. Толстого, М. Горького и мн. др. поддерживали читательский интерес к литературному творчеству, формировали отношение к человеческим качествам писателей, служили маркером выделения личности каждого изображаемого из общего литературного массива. Преобладание юмора или сатиры было напрямую связано с историческим контекстом, творчеством отдельного писателя, редакционной политикой изданий, позицией карикатуриста. Карикатуры начала XX века демонстрируют общественную атмосферу Серебряного века - творческую, переломную, нервную, свергающую кумиров ушедших эпох. Статья будет полезна для литературоведов, историков журналистики, исследователей визуального контента русской дореволюционной печати.

\section{Ключевые слова}

литературный канон; Российская империя; Серебряный век; русский писатель; русская дореволюционная журналистика; история образов; визуальные приемы; карикатура

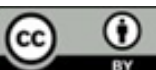

Это произведение доступно по лицензии Creative Commons «Attribution» («Атрибуция») 4.0 Всемирная 


\section{Введение}

За последние десятилетия в России вместе с определением «классика» широко стал использоваться термин «литературный канон». В бытовом сознании литературный канон воспринимается как список лучших национальных книг, на который ориентируются представители этой культуры. Согласимся с определением И.Н. Сухих, который трактовал литературный канон как

«перечень, список, собрание, множество текстов / авторов, считающихся образцовыми, самыми ценными, ключевыми для данной национальной литературы и / или культуры» (Сухих, 2016, с. 330).

Для данной статьи остановимся именно на «множестве авторов», т. к. карикатуры чаще всего создавались на личность, персоналию, а не на текст. Известный американский исследователь Г. Блюм, утверждая, что «без канона мы прекратим думать» (Блюм, 1995, с. 56), определял литературный канон так:

«Канон, если смотреть на него в ракурсе отношения частного читателя или писателя к тому, что было сохранено из написанного, и позабыть о каноне как о списке рекомендованных к прочтению книг, тождественен Искусству Памяти в его литературном аспекте» (с. 28).

Текстам русской классики посвящено огромное количество исследований. Тем не менее вопрос отражения общественных представлений о писателях, чьи произведения входили в литературный канон нашей страны, изучен слабее, особенно это касается сатирической графики. Существуют исследования, посвященные образу отдельного писателя в карикатуре, но их совсем немного; лучше всего изучена подборка карикатур на И.С. Тургенева (Клевенский, 1918, сс. 185-218; Фонякова, 1958, сс. 180-207).

Русская карикатура рубежа веков посвящена не только литераторам. В сатирической графике Первой русской революции и 1917 года лидируют политические темы, в годы Русско-японский и Первой мировой войн иллюстрированные журналы переполнены насмешками над противником. Много юмористических зарисовок на темы быта, семейных неурядиц, городских развлечений и т.п. Но все же немалое место уделяется культуре и особенно писателям как носителям сакрального знания в представлении русского читающего человека. При этом сатирический рисунок начала XX столетия по сравнению с карикатурами XIX века заметно упрощается: исчезают детали, проработанность; карикатуристы чаще играют пятнами и силуэтами.

Многие периодические издания публиковали циклы шаржей на беллетристов и журналистов: «Из альбома карикатур» в «Развлечении», «История современной русской литературы» Н.В. Ремизова в «Сатириконе», «Наши писатели» и «Наши поэты» в «Стрекозе», серии литературных кари- 
катур В.В. Каррика в «Лешем», «В кривом зеркале» М. Линского в «Искрах» и т.д. Выходили тематические номера иллюстрированных журналов, посвященных тому или иному литератору в связи с его юбилеем. Добродушные шаржи и едкие карикатуры на А.С. Пушкина, Н.В. Гоголя, Н.А. Некрасова, Л.Н. Толстого, А.П. Чехова, М. Горького и других поддерживали читательский интерес к литературному творчеству, формировали отношение к человеческим качествам писателей, служили маркером выделения личности каждого изображаемого из общего литературного массива.

Карикатура в легальной периодической печати является массовым визуальным искусством, и образ русского литератора, встречающийся в сатирической графике, будет демонстрировать отношение редакции и художника к его творчеству. Целью исследования стало изучение частотности изображений отечественных литераторов в сатирической графике начала XX века как отражения сформированного и дополняемого литературного канона России. Отсюда вытекают задачи: выявление изображений литераторов, встречающихся в сатирической графике; сопоставление приемов показа литераторов в карикатуре XIX и начала XX веков; вычленение визуальных мотивов противопоставления литературы прошлого и современности, кочующих сатирических образов, смысловых акцентов изображения крупных литературных имен в зависимости от читательского адреса периодического издания.

\section{Методы}

Важно понять, что в случае с визуальной сатирой, посвященной литераторам,

«речь может идти о двух типах пародийно-сатирического контекста. Первый тип обусловлен восприятием писателя в узкой литературной среде, /.../ второй тип контекста обусловлен восприятием литературной личности массовой аудиторией, которой автор не известен как человек, а представлен дистанционно» (Вахненко, 2019, с. 171).

Выбирались карикатуры, рассчитанные на публичное (массовое) знакомство с образом русского известного писателя (прозаика, поэта, литературного или художественного критика, публициста). На основе выборочного просмотра 25 тонких иллюстрированных журналов и двух газет 1877-1917 годов было выявлено более 200 карикатур и шаржей, посвященных отечественному литератору. Сатирические рисунки искались по нескольким признакам. Во-первых, по портретному сходству с литераторами выбранного периода или по пояснительным текстам в заголовках, внутри рисунков или подписи. Во-вторых, по традиционному набору символических предметов, которым художники окружали образы литераторов (арфы, лиры, гусиные перья, лавровые венки, рукописи, книги и т.д.). Кроме того, в сатирической графике писателям часто «воздвигали» памятники, изображая реально существующие или вымышленные монументы. Наконец, иной визуальный контекст карика- 
туры (полемика, сцена в книжном магазине и пр.) мог подсказать ее литературную направленность. Все эти признаки могли быть представлены на рисунках вместе или по отдельности; но встречались и карикатуры без характерных визуальных отсылок к писательскому труду.

Исходя из этого опыта, можно, к сожалению, предположить, что ряд карикатур, посвященных литераторам, остался неузнанным и потому пропущенным, что не позволяет сделать утверждение о полностью репрезентативной выборке сатирических рисунков. Тем не менее, учитывая внушительное количество выявленных карикатур, можно сделать предварительные выводы о характере и частотности изображения литератора в русской сатирической графике.

Для понимания сатирических рисунков использовался контекстный метод, для включения их в текст статьи - нарративный. К обнаруженным карикатурам частично применялся метод «история образов» для вычленения повторяющихся образов и определения выраженного отношения редакций и художников к изображаемому отдельному литератору и писательскому труду в целом.

Для систематизации выявленных карикатур возьмем за основу классификацию их задач, предложенную историком искусства Б.Р. Виппером (1970, сс. 130-131). Современные определения функций карикатуры интересны например, очень перспективного исследователя А.С. Айнутдинова (2010), но выполнены на современном материале и далеко не всегда применимы к сатирическим рисункам прошлого.

\section{Результаты}

Юмористический или сатирический образ русского писателя в дореволюционной журналистике России формировался постепенно. Первые сатирические изображения известных писателей встречаются в отечественных журналах 1840-х годов. В «Ералаше» Михаила Неваховича 1846 года дан коллективный шаржированный портрет русских литераторов и издателей (В.А. Жуковского, П.А. Вяземского, И.И. Панаева, Н.В. Кукольника, Н.И. Гнедича, Н.В. Гоголя, В.Ф. Одоевского, Ф.В. Булгарина, А.А. Краевского и др.) (Невахович, 1846, л. 24). При этом известность писателя гарантирует изображение в центре карикатуры: Гоголь спит на втором томе «Мертвых душ», возвышаясь над всеми и привлекая к себе внимание. Если писатель начинал литературный путь, то ему был уготован лишь край рисунка (как это произошло с изображением юного на ту пору Н.А. Некрасова). Писатели шествуют в Храм славы, при этом шлагбаум поднимает (т.е. не препятствует движению) цензор А.Н. Очкин, что является редчайшей в русской сатире визуальной фиксацией доброжелательного отношения к цензору.

Традиции коллективного изображения литераторов продолжаются и дальше. Отметим, например, пародию на картину И.Е. Репина «Бурлаки на 
Волге» 1879 года, где знаменитые писатели в роли бурлаков с усилиями тянут огромную чернильницу, олицетворяющую русскую литературу («На мель села, голубушка!..», 1879, с. 1). Довольно часто во второй половине XIX века встречаются карикатуры, где писатели и издатели играют в оркестре или поют в хоре, состязаются за деньги подписчиков на средневековых ристалищах или цирковых аренах (Борель, 1863; Жуковский, 1864; Иевлев, 1863).

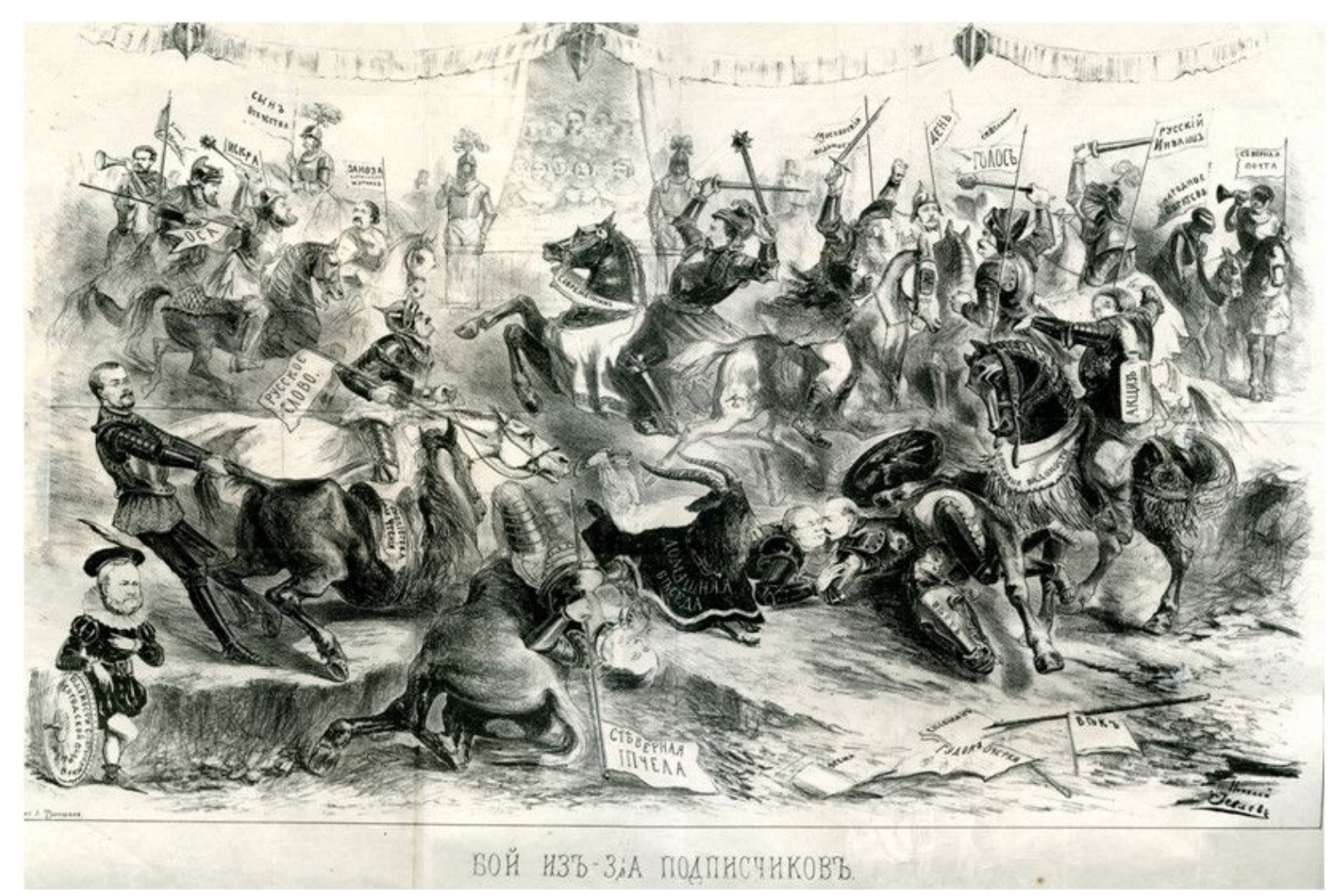

Рисунок 1. Иевлев, Н.И. (1863). Бой из-за подписчиков. Заноза, 47 (8 декабря).

Figure 1. Ievlev, N.I. (1863). Fighting over subscribers. Splinter, 47 (December 8).

При этом, как правило, литераторов изображают с портретным сходством, а во избежание недоразумений мелким шрифтом даются пояснения, кто где нарисован (на музыкальных инструментах, уздечках коней или любых других аксессуарах приписываются названия произведений или изданий, ассоциируемых с писательскими именами). Интересно, что на сатирических рисунках начала XX века коллективное изображение литераторов встречается значительно реже.

Рассмотрим карикатуры рубежа XIX-XX веков в соответствии с выполнением ими определенных задач. 


\section{«Прежде всего карикатура должна оставлять комическое впечатление» (Виппер, 1970, с. 130)}

Карикатура всегда высмеивает, и сатирические рисунки на литературные темы не являются исключением. Как правило, острие насмешки направлено не на писателя, а на окружающую его действительность или людей.

В этом аспекте интересно взглянуть на повторяющиеся сатирические образы. К таким относится, например, осел, попирающий память о великом человеке. Осел как аллюзия на невежество лягает том романа И.С. Тургенева «Новь» (так художник показал критика еженедельника «Московское обозрение», осудившего последний роман писателя) («О времена, о нравы!», 1877). В ослов, копытами пинающих бюст А.С. Пушкина, превращаются представители городских дум, которые не желают тратить деньги на установку памятника поэту («Календарь “Стрекозы". Май», 1900). Оригинальна карикатура в «Огоньке» 1913 года: после скандального цикла лекций «Пушкин и Хлебников» Д.Д. Бурлюк был изображен в виде осла, задними копытами отбрасывающего комки грязи в постамент памятника А.С. Пушкину в Москве (Животовский, 1913, с. 13). Велимир Хлебников показан в виде крохотной мартышки, сидящей на крупе у осла-Бурлюка и поднимающей ослиный хвост вверх. На заднем плане видна разъяренная толпа.

Ю.А. Молок считает, что изображение осла связано с обществом художников-модернистов «Ослиный хвост» (Молок, 2000). Но образ осла, попирающего памятник/бюст/книгу, появляется в сатирической графике задолго до основания художественной группы М.Ф. Ларионова и Н.С. Гончаровой. Периодически встречающимся образом можно считать и тень скончавшегося литератора. Как правило, на рисунке идет противопоставление неба и земли, умершего и живущих, прошлого и современности. Почивший писатель с удивлением взирает на своих последователей, которые больше озабочены собственной славой, чем памятью о великом человеке. Интересен сюжет с В.Г. Белинским. Карикатурист А.М. Хлещенко изобразил критика в разговоре с издателем «Отечественных записок» А.А. Краевским в виде скелета, но вербальная часть рисунка открывается уточнением: «Тень труженикакритика» (Хлещенко, 1860, с. 137). Снова не тень, а скелет Белинского выглядывает из раскрытого переплета «Отечественных записок», ужасаясь переходу журнала от А.А. Краевского к Н.А. Некрасову (Волков, 1868). Тени В.Г. Белинского и Д.И. Писарева страдают от юбилейной какофонии, которую в их честь устроила русская пресса (Калабановский, 1898). 

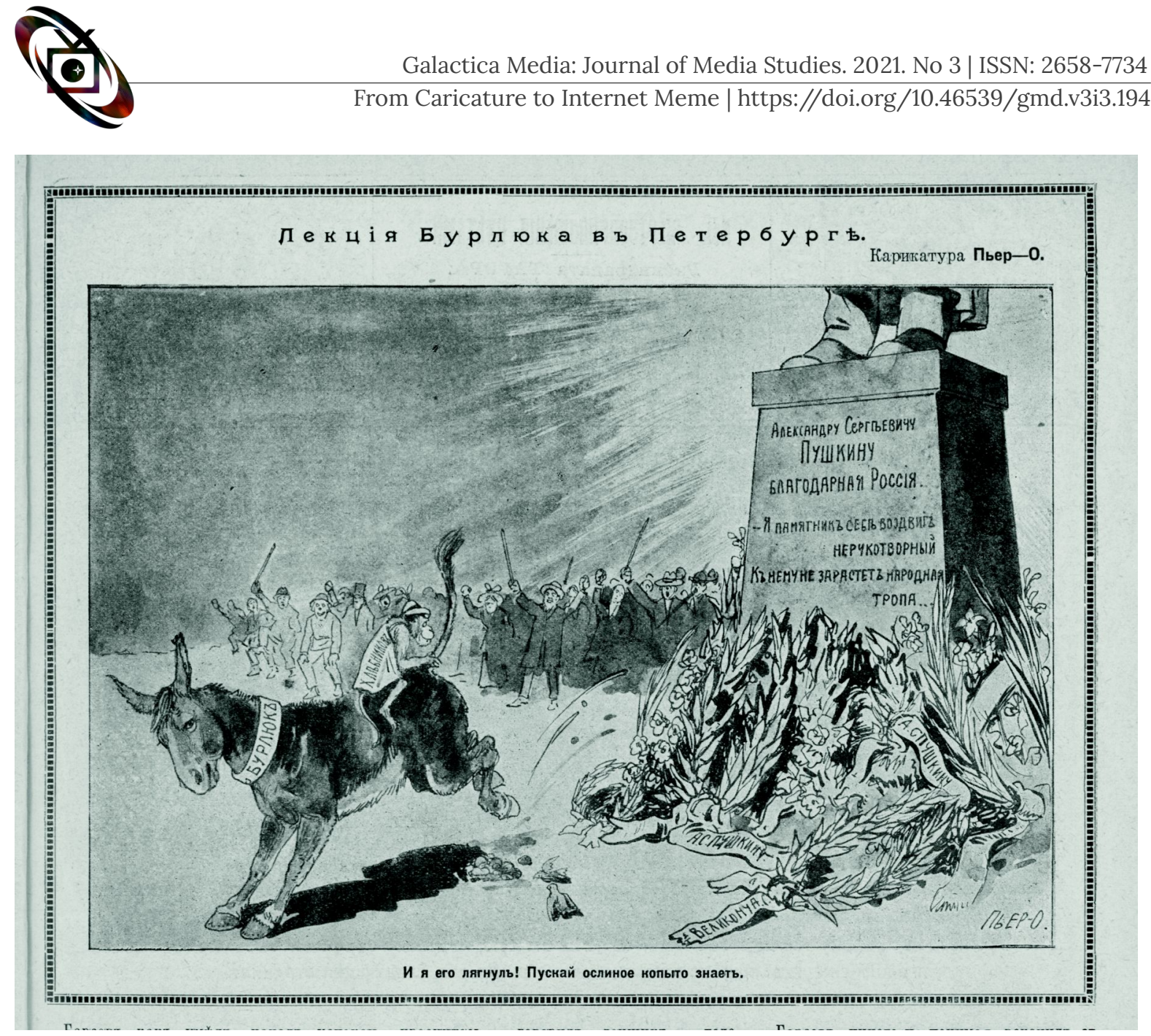

Рисунок 2. Животовский, С.В. (1913). Лекция Бурлюка в Петербурге. Огонек, 45 (10 ноября), 13.

Figure 2. Zhivotovsky, S.V. (1913). Burliuk's lecture in St. Petersburg. Ogonyok, 45 (November 10), 13.

Визуализация идеологических, экономических и прочих споров тоже дается через прием с тенями. Тень А.С. Пушкина интересуется, почему памятник ему ставят в Москве, а не Петербурге, а тень организатора праздника отвечает, опираясь на строки поэта «Москва! Как много в этом звуке» («В царстве теней», 1880). Тени И.С. Тургенева и И.С. Аксакова пытаются посвоему объяснить русскому мужику, куда ведет правильный путь (так визуализирован спор западников и славянофилов) (Чемоданов, 1881). В гоголевском номере «Сатирикона» тень Н.В. Гоголя посмеивается над жандармами, которые не могут решить, «не пущать или тащить» посетителей на юбилей писателя (Ремизов, 1909, с. 1). Тень А.П. Чехова вслушивается в поминальные речи, которые прямо противоположны его вкусам (Ремизов, 1910, с. 1). М.Ю. Лермонтов и А.Н. Островский с глубокой тоской взирают с небес на режиссерско-актерские склоки у стен Александринского театра (Тэдди, 1917, c. 1). 
Среди мишеней карикатуристов обязательно находятся поклонники литераторов. Например, памятник А.С. Пушкину в Москве печально смотрит на поэтов, которые жаждут взобраться на его пьедестал («Пушкинские дни», 1899). Петербургский памятник ему же включается в живое обсуждение насущных проблем, обращаясь к митингующим «О чем шумите вы, народные витии?» («В Пушкинском сквере», 1906). Нередко встречаются карикатуры, где А.С. Пушкина с постамента либо изгоняют самодовольные стихоплеты («Пров Елдырин, мастеровой человек, Пушкина с пьедестала стряхнул, сам встал и стихи сочинил», 1917, с. 16), либо стаскивают издатели, стремящиеся доказать исключительные права на него (Далькевич, 1887). Бывает, что А.С. Пушкин уходит с постамента сам, устав от поклонников новых поэтов или споря с топонимическими решениями властей («Морозная фантазия», 1899; «Орел с места - вороны на место», 1883). Много карикатур и с памятниками Н.В. Гоголю (Радаков, 1909, с. 12). При этом, как правило, в запечатленных памятниках можно усмотреть формулы пафоса Аби Варбурга: скульптуры неизменно смотрят на поклонников сверху вниз, и не только из-за величины постаментов, но и благодаря несоизмеримой духовной величине писателей. Огромный масштаб личности Л.Н. Толстого стал одним из лейтмотивов карикатур; часто художниками используются диспропорции роста: так, Лев Толстой изображен выше А.П. Чехова на одну треть, М. Горького на половину, а крохотный Л.Н. Андреев умещается на толстовской ладони («K LXXV-летнему юбилею графа Л.Н. Толстого», 1903, с. 1). Идея непротивления злу, непонятная большинству зрителей, чаще подавалась карикатуристами не в философском, а в бытовом ключе: Толстой отказывается от чая, трубит о непротивлении злу и не мешает плагиаторам резать роман «Воскресение» («Л.Н. Толстой как современный философ», 1905, с. 1; «Не противься злу», 1904, с. 16; Ремизов, 1907, с. 9). Юбилей породил немало карикатур не столько на Л.Н. Толстого, сколько на общественный ажиотаж по этому поводу. Выходит специальный номер «Сатирикона», посвященный графу (1908, № 21, 28 августа); некоторые журналы в каждом выпуске помещают карикатуры из яснополянской жизни (особенно отличился этим «Серый волк»). Общественный гиперболизированный резонанс был настолько утомителен для юбиляра, что даже появляется карикатура, где Л.Н. Толстой, оседлав коня, мчится прочь от устроителей собственного юбилея (Боб, 1908, с. 11). 


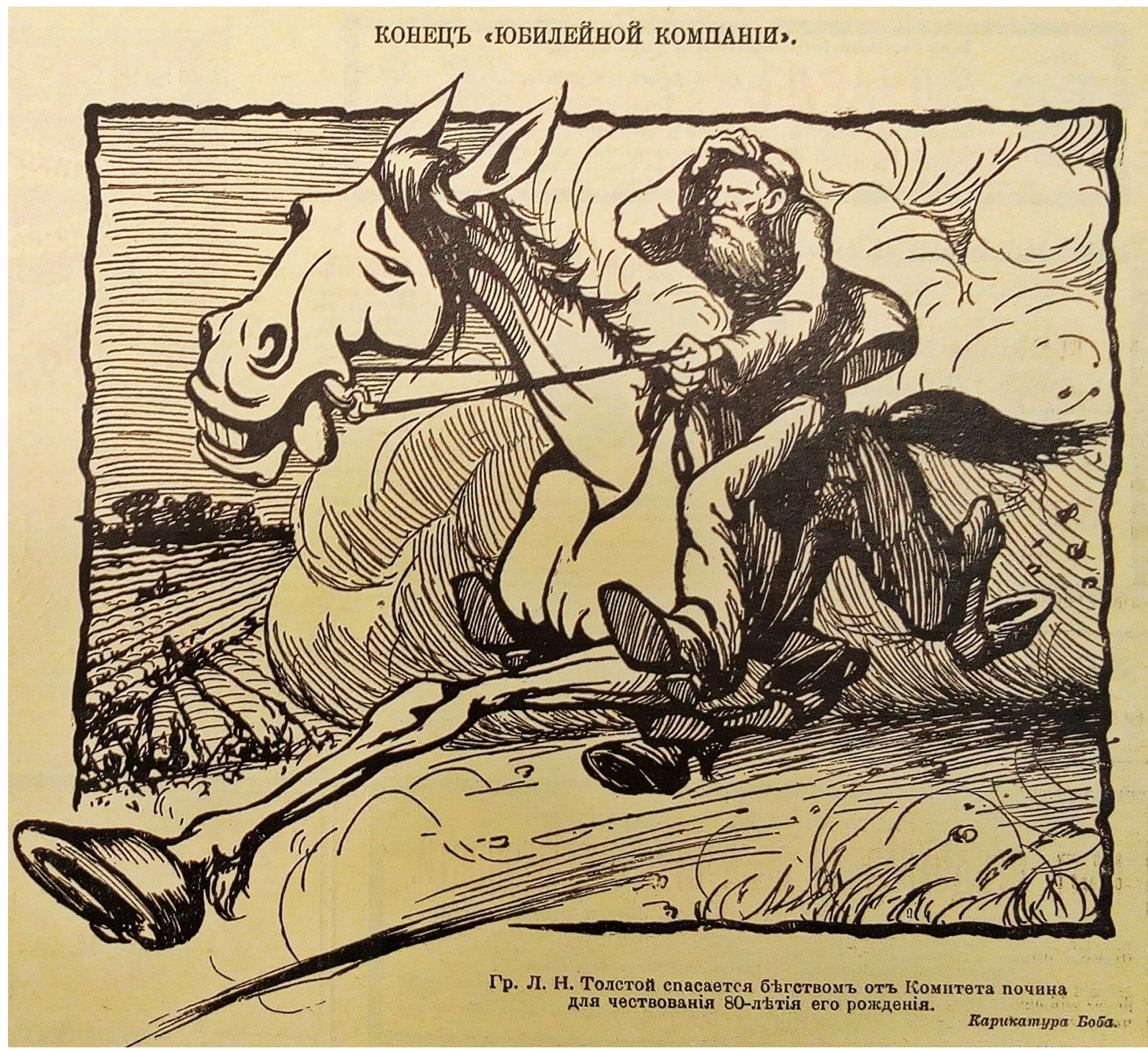

Рисунок 3. Боб (1908). Конец «юбилейной кампании».

Новое время, иллюстрированное приложение, 11515 (2 апреля), 11.

Figure 3. Bob (1908). The end of the "Jubilee Campaign." Novoe Vremya, Illustrated Supplement, 11515 (April 2), 11.

В этих и подобных карикатурах комическое впечатление часто возникает благодаря утрированным образам, неожиданным сюжетным ходам или вербальной составляющей рисунков.

\section{«Карикатура всегда обращается против личности, факта, конкретного явления» (Виппер, 1970, с. 130)}

Опираясь на свойственные людям ностальгические воспоминания, карикатуристы эксплуатируют тему противопоставления литературы «раньше и теперь». Прошлое объявляется благородным, современность - алчной. Литера- 
турные представители ушедшей эпохи изображены носителями светоча правды, эпохи современной - дельцами с тугими денежными мешками и канканом (Свириденко, 1903, с. 1). Но этот пример посвящен абстрактным писателям и публицистам; можно найти случаи сатирического сравнения реально живших литераторов. Так, в полиптихе 1908 года сопоставляется отношение к женщинам у писателей галантной эпохи (Н.М. Карамзин, И.С. Тургенев) и современных творцов (М. Горький, В.Я. Брюсов) (Юнгер, 1908, с. 8). Брюсову припомнили в карикатуре эротический подтекст с козой в его стихотворении "In hac lacrimarum valle", а Горькому - увлечение босячеством; Карамзин и Тургенев же нелепы в утонченной напыщенности. Реплики всех четверых литераторов построены в виде интертекста.

Приемом, рассчитанным на смех зрителя, является столкновение представителей разных литературных эпох. В Серебряный век обращения к великим именам прошлого, как правило, связаны с актуализацией истории. Часто писатели начала XX века пытаются сравняться с мастерами XIX столетия. Именно так вышло в рисунках, изображающих Л.Н. Андреева (который старается стать «вровень» с Ф.М. Достоевским) и абстрактного литератора, сравнивающего себя с Н.А. Некрасовым («Написав "Милых призраков”, я начинаю думать...», 1917; «Современный писатель», 1903, с. 6). Иногда сопоставление показано через призму восприятия в обществе литературного наследия двух писателей: И.С. Тургенев просит устроителей чествования Л.Н. Толстого не забыть и про его юбилей, на что автору «Отцов и детей» и «Дворянского гнезда» чванливо отвечают: «А вы кто будете?» («Мне хотя бы плохонькую подкомиссию...», 1908, с. 9). А в иллюстрации 1903 года встречаются шесть богатырей (аллюзия на картину В.М. Васнецова): представители старой литературы - Л.Н. Толстой, В.Г. Короленко, А.П. Чехов и новое поколение - М. Горький, Л.Н. Андреев, Скиталец («Без названия», сс. 8-9, 1903). «Старики» на конях, в богатырских кольчугах, с копьями и мечами; «молодежь» босяцкого вида, на снопах соломы, с балалайкой и бутылкой. Вербальная часть карикатуры подчеркивает уверенность старших литераторов в себе и несерьезность, поверхностность младших. 
Galactica Media: Journal of Media Studies. 2021. No 3 | ISSN: 2658-7734

From Caricature to Internet Meme | https://doi.org/10.46539/gmd.v3i3.194

ЛЮБОВЬ В' ОТЕЧЕСТВЕННОЙ .ИТЕРАТУРТ.

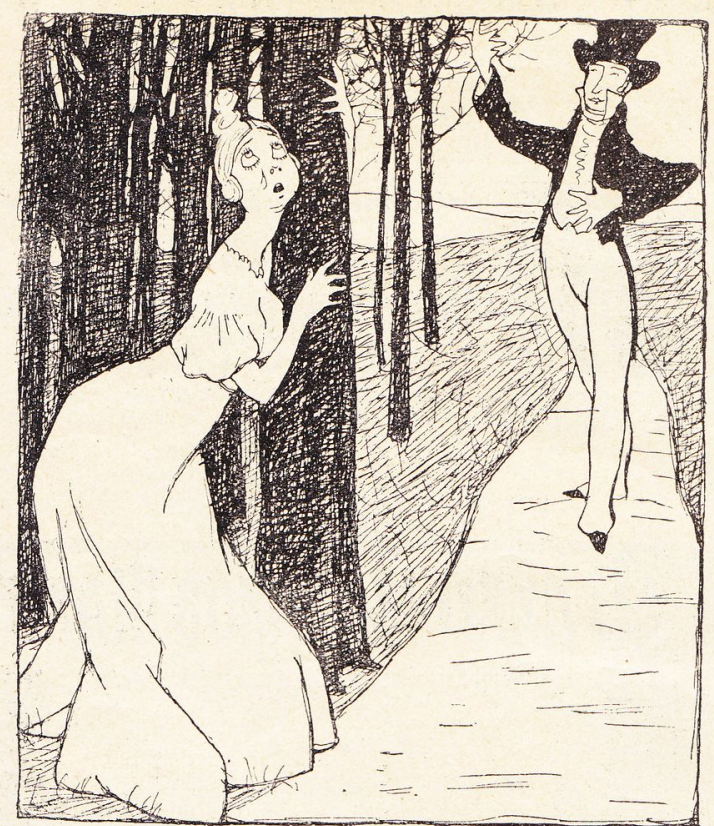

Kaparsanr - Tus, J

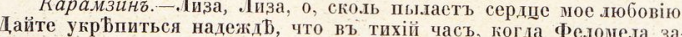

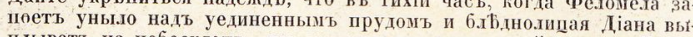

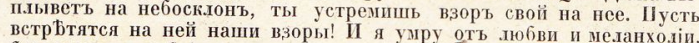
встрБтяся на ней наши взоры! И я умру отъ любви и механходіи, Бъдная Лиза.-Боже! Укрђпи меня! Какъ я пала, какт низко
па.ла!..

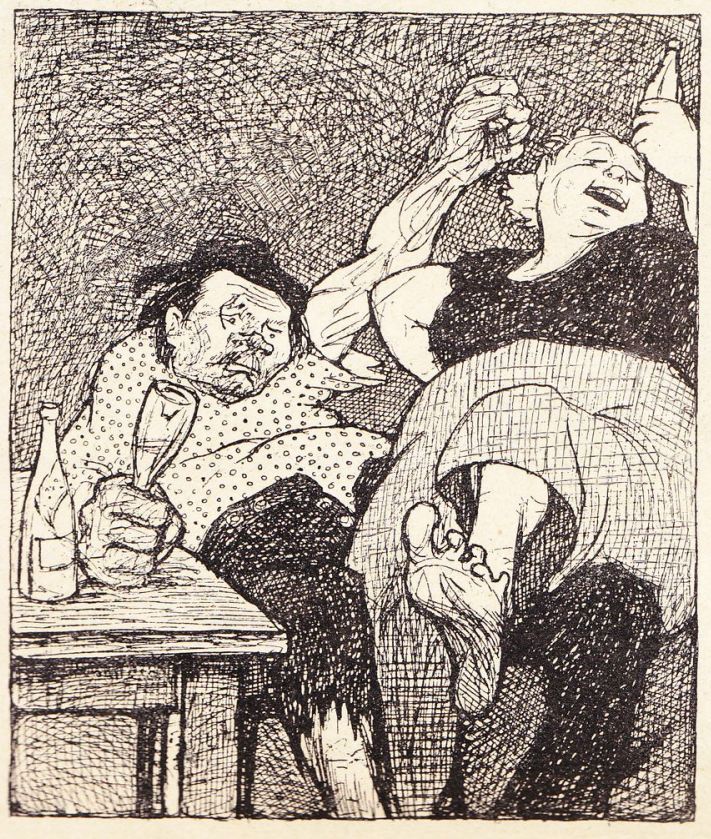

Горькій.-Брысъ, гнва!' Свушно мнђ съ тобой, чертиха ладовая.

Рисунок 4. Юнгер, А. (1908). Любовь в отечественной литературе. Сатирикон, 2, 8.

Figure 4. Junger, A. (1908). Love in Domestic Literature. Satyricon, 2, 8.
Puc. Баяна.

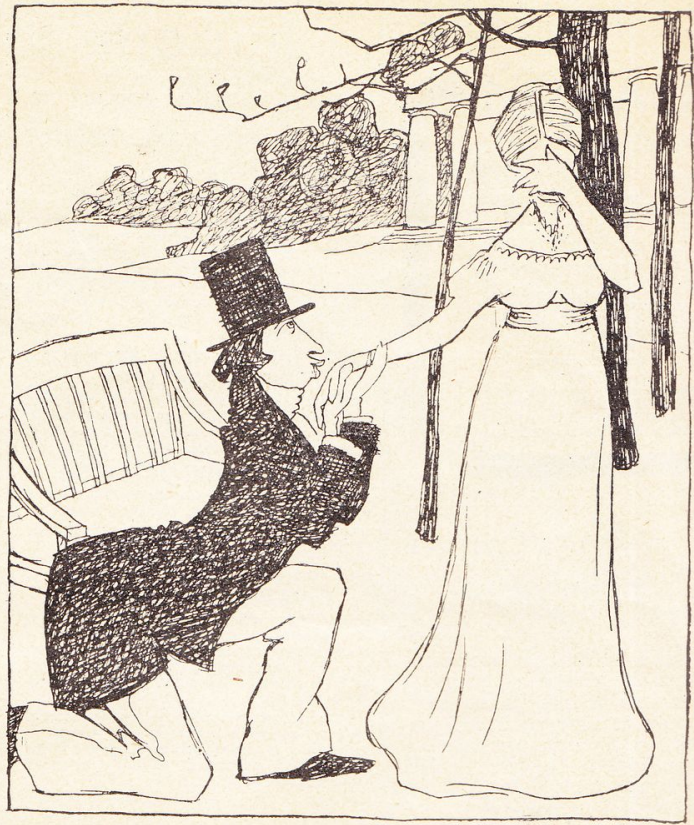

Тургеневб. - Я опять у вашихь ногъ, .Іиза, и прежніе образ проснулись въ моей душђ Въ да.гекомъ Парижђ я жиль воспони наніями о васъ, о нашемъ первомъ свиданіи въ старомъ паркћ, розы! 0 , счастье! неужели ты ускользнуло изъ судорожно сжатых рукъ моихъ?.. Пропайте, Лиза, я опять у бзжаю въ Парижъ, чтобь былы розы!

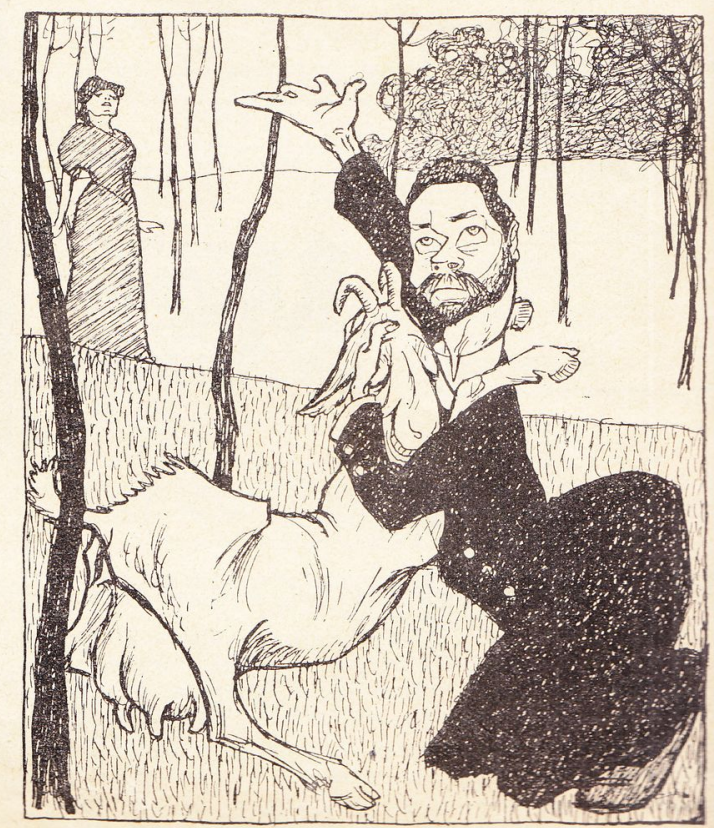

Женцина.-Поэть, а лю6лю тебв! 
Galactica Media: Journal of Media Studies. 2021. No 3 | ISSN: 2658-7734

От карикатуры до интернет-мема | https://doi.org/10.46539/gmd.v3i3.194
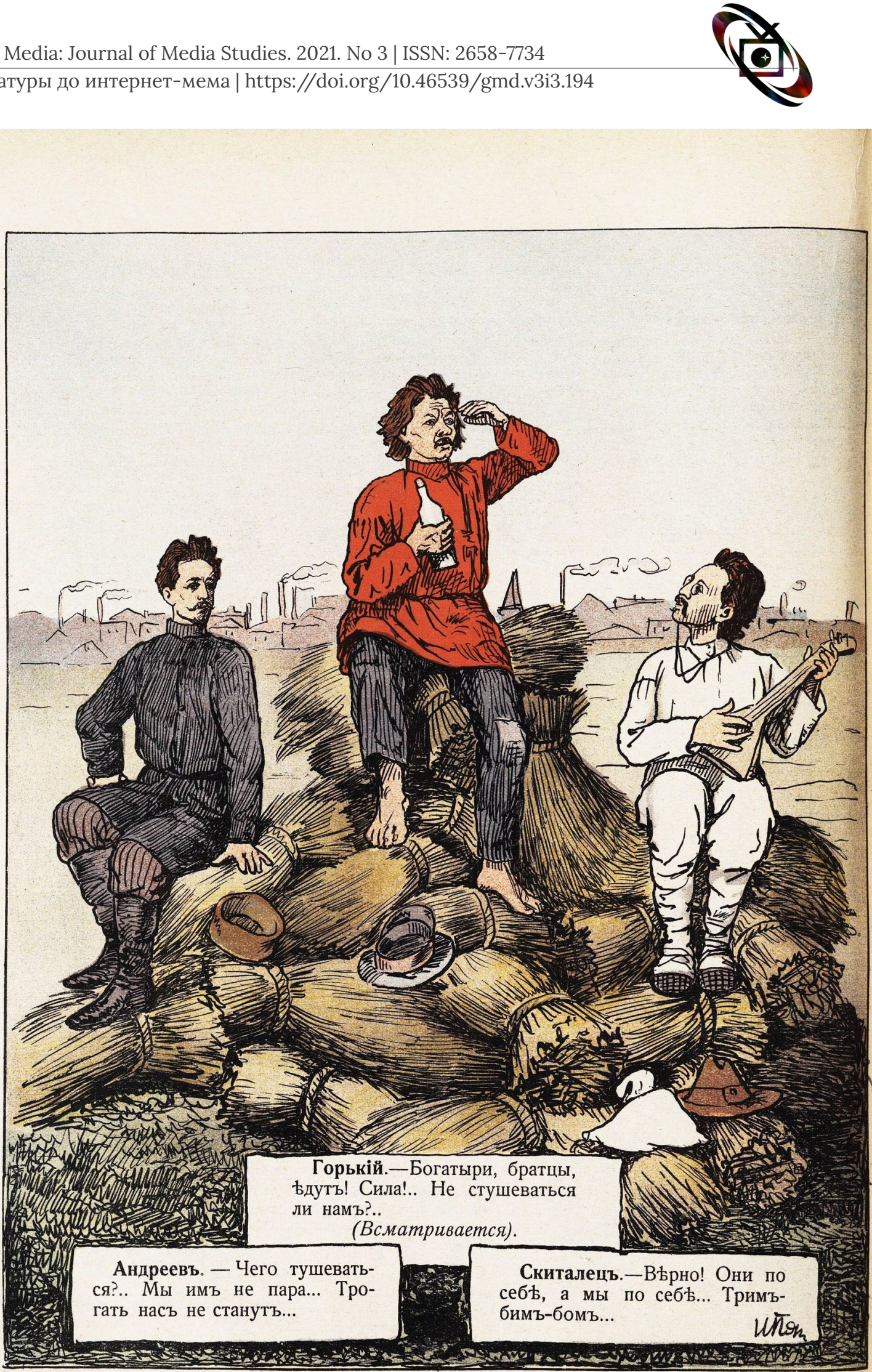
Galactica Media: Journal of Media Studies. 2021. No 3 | ISSN: 2658-7734

From Caricature to Internet Meme | https://doi.org/10.46539/gmd.v3i3.194

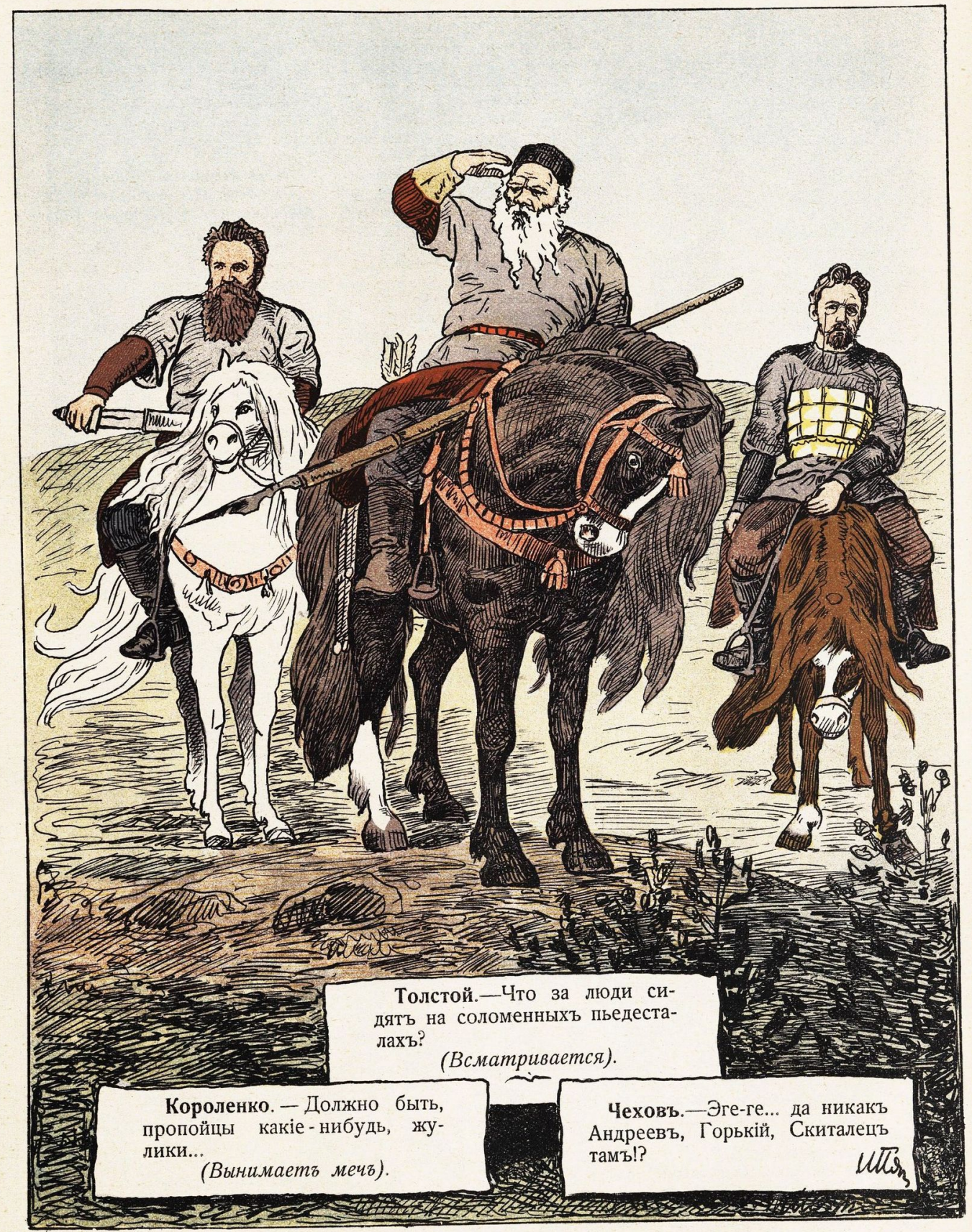

Рисунки 5-1 и 5-2. Без подписи (1903а). Без названия. Шут, 41 (11 октября), 8-9.

Figures 5-1 and 5-2. Unsigned (1903a). Untitled. Jester, 41 (October 11), 8-9. 
Но далеко не всегда карикатуристы вставали на путь осмеяния новой литературы. Часто встречаются визуальные отражения победы нынешних литераторов над писателями ушедших эпох. Именно так подан сюжет борьбы между антропоморфными изображениями сочинений М.П. Арцыбашева и И.А. Гончарова, И.С. Тургенева, Ф.М. Достоевского, Л.Н. Толстого (Калабановский, 1909). Авторы изображены людьми с туловищами в виде больших томов, на корешках которых выведены фамилии или заглавия произведений. Популярный в начале XX века роман Арцыбашева «Санин» в сражении с классиками одерживает верх.

Появляется немало обличительных рисунков на тех, кто живет плодами чужого труда. Так, повернувшийся спиной и потому безликий прозектор огромным ножом кромсает тела И.С. Тургенева и Ф.М. Достоевского, переделывая литературные шедевры в якобы свои пьесы и водевили (Штейн, 1900).

Есть и рисунки, высмеивающие невежество российского обывателя. Например, в карикатуре 1908 года на тумбе с театральным репертуаром прохожий видит афишу спектакля «Смерть Пушкина» и печалится: «Умер-таки, бедняга /.../ А еще на прошлой неделе я его сочинения покупал» («Печальная неожиданность», 1908, с. 3).

Бывает так, что обличение в карикатуре еще надо понять. Например, трудно догадаться, что клеймит внешне спокойный рисунок: прохожий недоумевает при виде памятной доски «В этом доме 29 января 1837 года скончался Александр Сергеевич Пушкин»: «Скончался Пушкин! А живет-то кто?» («Без названия», 1907, с. 84).

Не зная контекста, можно лишь предположить, что в подписи заключена непонятная игра слов. Но ответ находится с помощью другой карикатуры: А.С. Пушкин, не слишком похожий на себя (ключевые бакенбарды тщательно прорисованы), шлет воздушный поцелуй отчаливающему на венецианской гондоле жандарму: «Прощаюсь, ангел мой, с тобою...» («Сцена на Мойке (к выселению Охранного отделения)», 1907). Отделение по охранению общественной безопасности и порядка в Санкт-Петербурге (охранное отделение) вселилось в здание на Мойке в декабре 1901 года. Но в исследовательской литературе, как правило, не указывается время выезда охранки из сакрального для русских людей места. Карикатура «Руси» 1907 года может не только подсказать эту дату, но и объяснить зрителю XXI века, что вызывало раздражение у художника начала XX столетия.

«Добренькой», слащавой карикатура быть не может. Карикатуристы постоянно подчеркивают привязанность М. Горького к босякам и алкоголю, утверждая даже, что литературные идеи писатель черпает на общественных помойках («Новейшие литературные “залежи”», 1904, с. 5). Помимо широко распространенных тем увлечения Горьким босячеством и маргинализации, художники часто останавливались на подробностях личной жизни писателя (дружба с Ф.И. Шаляпиным, сложности из-за гражданского брака, скандалы и пр.). 
Galactica Media: Journal of Media Studies. 2021. No 3 | ISSN: 2658-7734

From Caricature to Internet Meme | https://doi.org/10.46539/gmd.v3i3.194

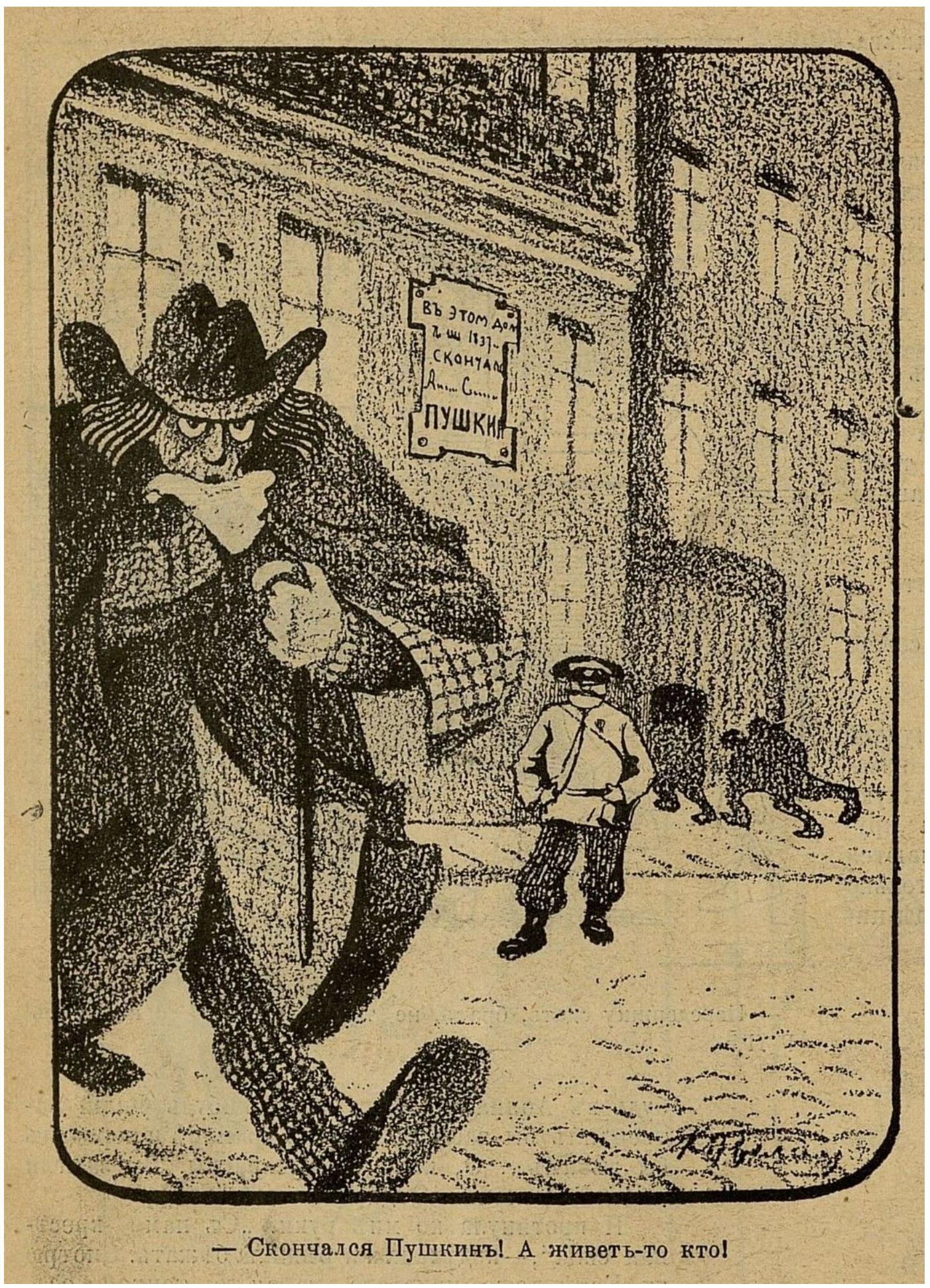

Рисунок 6. Без названия. (1907а). Серый волк, 5 (5 августа), 84.

Figure 6. Untitled. (1907a). Gray Wolf, 5 (5 August), 84. 
Galactica Media: Journal of Media Studies. 2021. No 3 | ISSN: 2658-7734

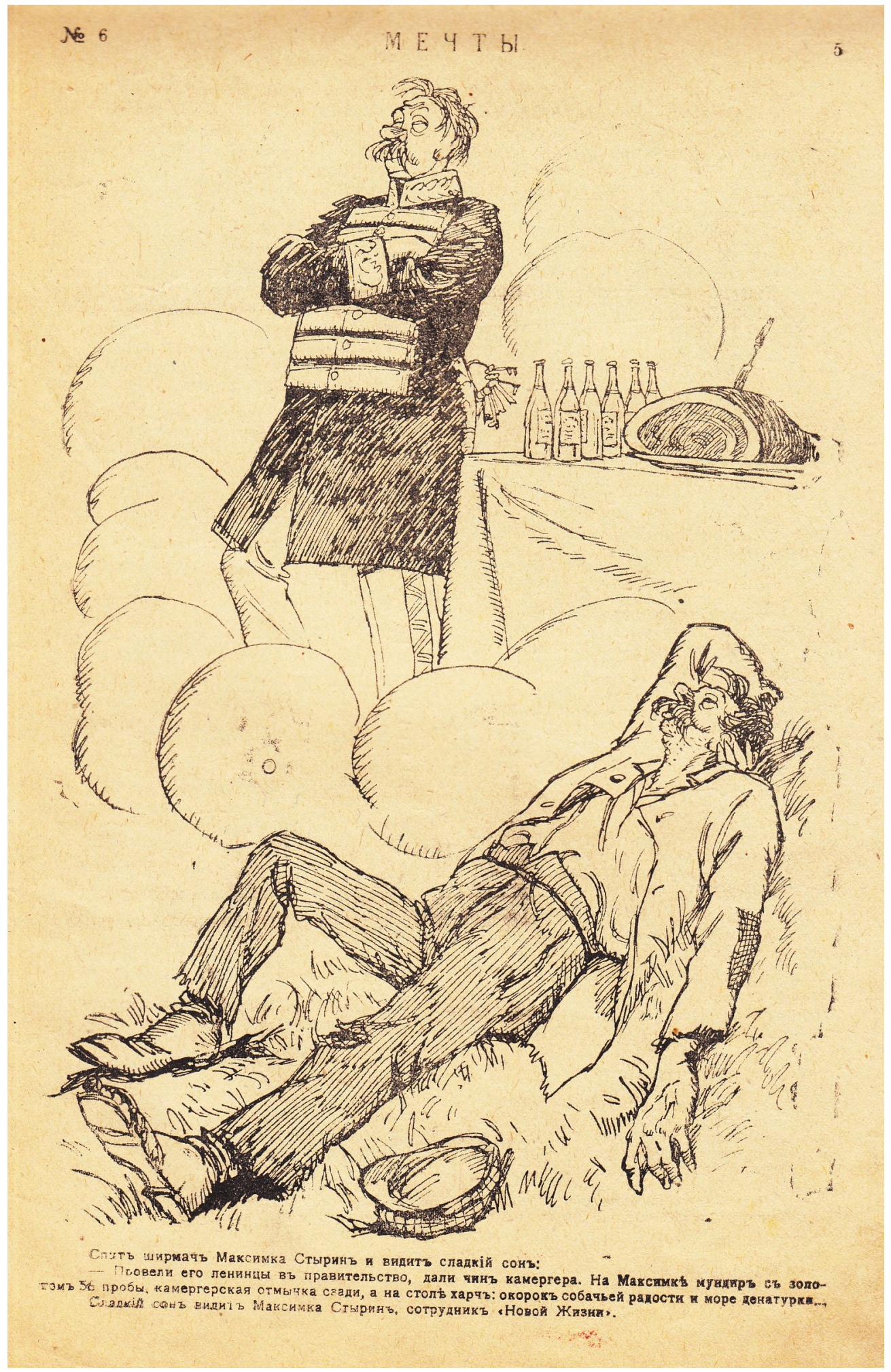

Рисунок 7. Без подписи (1917). Мечты. Трепач, 6, 5.

Figure 7. unsigned (1917). Dreams. Trepach, 6, 5.

Кроме того, среди карикатур на Горького есть острые рисунки, связанные с его публицистической и издательской деятельностью. Сатириками всячески 
перепевается тема «Новой жизни» - газеты, в 1917 г. основанной и издававшейся при его основном участии. Карикатуры 1917 года, опубликованные до прихода большевиков к власти, позволили художникам продемонстрировать изменчивые политические взгляды Горького. Участие писателя в «Новой жизни» обыгрывается по-разному: то он наездник на Аничковом мосту Петербурга, сам себе воздвигший памятник (Симаков, 1917, с. 16), то прикрывает газетным листом готового к поножовщине большевика, «защищая» его от испуганного прохожего (Лебедев, 1917, с. 1). В диптихе «Вечернего времени» Горький показан как в прошлом - оборванным писателем, боровшемся с нищетой, так и в настоящем - франтовато одетым, сидящим на мешках с деньгами, но начавшим «"Новую жизнь”, полную борьбы с капиталом» (Матюнин, 1917, с. 1). Иногда прозаика якобы обуревают сомнения в правильности выбранного пути (Рожон, 1917, с. 5). Все эти рисунки не просто фиксируют изменчивость взглядов Горького, но и довольно резко осуждают его.

\section{«Она поучает, воспитывает, агитирует, борется» (Виппер, 1970, с. 130)}

Карикатуры, посвященные писателям, не могли не затронуть тему взаимоотношений внутри литературного цеха; при этом художниками стирались временные и географические рамки между мастерами слова. Зрители сквозь сатирическую призму не только узнавали (или вспоминали) о литературной вражде-дружбе, но и получали определенный нравственный урок (детали же этого послания зависели прежде всего от установок редакций).

В карикатурах на Л.Н. Толстого очень интересен акцент, связанный с отношением великого русского писателя к великому английскому писателю - У. Шекспиру. Статья Толстого «О Шекспире и его драме» появилась в газете «Русское слово» в 1906 году, в 1907 году вышла отдельным изданием на русском и на английском языках. Она была написана в 1903 году, задумывалась как предисловие к статье Э. Кросби «Шекспир и рабочий класс». Толстой упрекал Шекспира в неоригинальности, отсутствии чувства меры, нежизненности героев и ситуаций, утверждал, что именно журналистика раздула культ драматурга. Профессор Йельского университета Г. Блум считал, что в центре западного канона находится Шекспир: «Без Шекспира нет канона» (Блюм, 1995, с. 56), а в центре русского - Лев Толстой, что для нас несколько неожиданно. Если верить Блуму, то в этих креолизованных текстах сталкиваются два центра канонов. Бунт Толстого против культа Шекспира (в виде критического разбора «Короля Лира») вызвал мощную полемику в прессе, что не могло не отразиться в карикатурах. Сатирики изображали Толстого, босой ногой попирающего рукописи Шекспира, лопатой подрывающего постамент памятника английскому драматургу и даже разбивающего бюст Шекспира во время спиритической встречи с ним («Великому Шекспиру», 1907, с. 14; «Спиритический сеанс в Ясной Поляне», 1907, с. 1; «Эх, как мозги-то мои почернели», 1907, с. 1). 


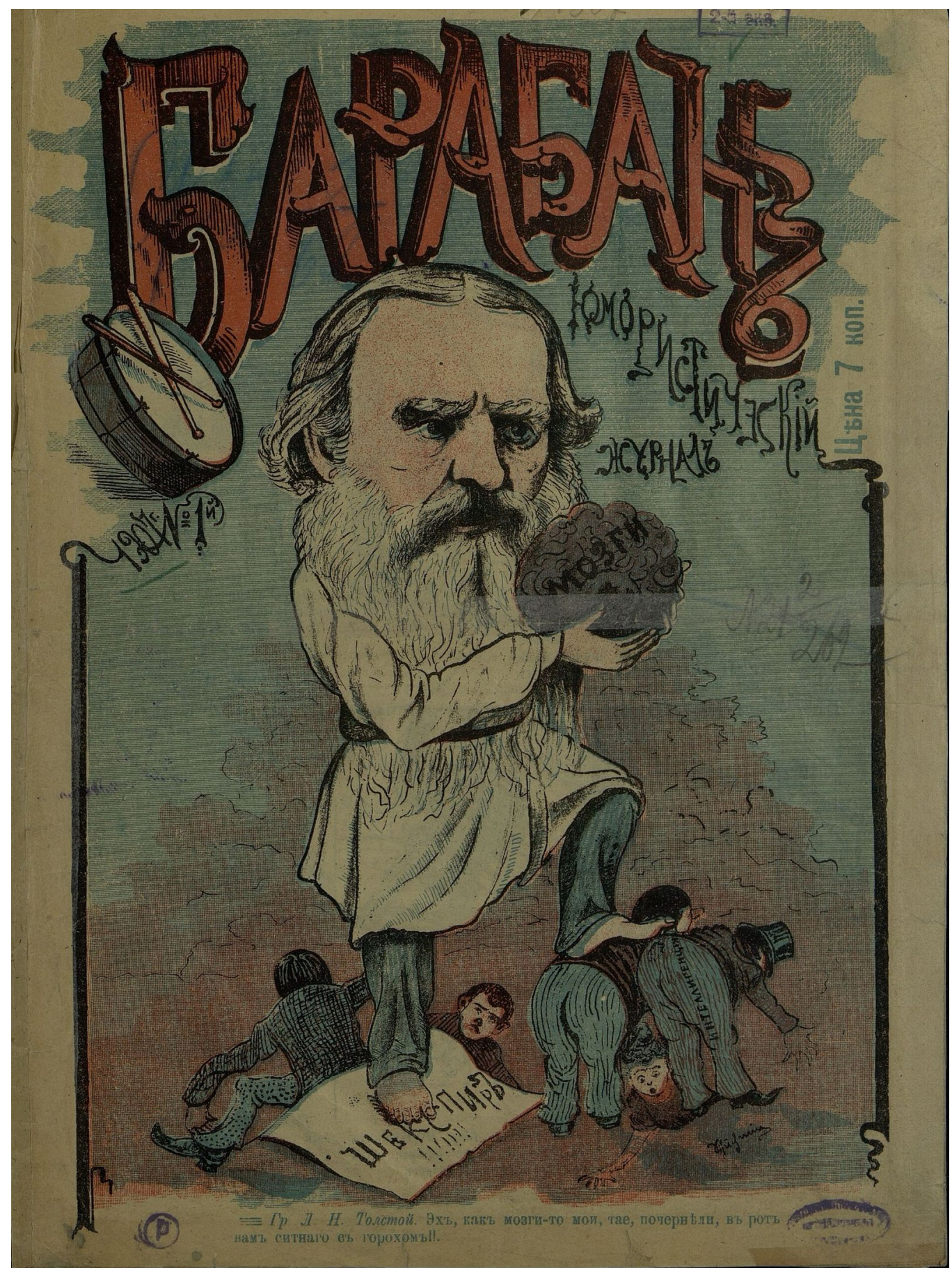

Рисунок 8. Без подписи (1907д). Эх, как мозги-то мои почернели. Барабан, 1, 1.

Figure 8. unsigned (1907d). Eh, how my brains have turned black. Drum, 1, 1.

Если неприятие Толстым Шекспира отражалось в карикатурах как соперничество равных писателей разных эпох, то литературных последователей Горького пренебрежительно называли «подмаксимовиками» или «подмаксимками». Эти слова сформировались под влиянием успеха карикатуры, 
где художник Н.Н. Фидели изобразил Горького в виде гриба, а у подножия его подрастают Л. Андреев, И.А. Бунин и Скиталец (Фидели, 1903, с. 34). О влиянии Горького на Андреева и Скитальца (а также Чехова на Бунина и Е.Н. Чирикова) говорит карикатура, где две бутылки спиртного настаиваются на голове Горького и заткнуты фигурными пробками в виде Андреева и Скитальца (другие бутылки повторяют процедуру с остальными авторами) (Mersu, 1903, с. 33). Часто используются зооморфные образы птиц, лягушек и пр.: например, Горький, Андреев и Скиталец изображены петухами, забрызгивающими грязью публику («Беллетристы нового века», 1903, сс. 8-9).

\section{Заключение}

Сегодня прочесть смысл, заложенный художниками в карикатуру далекого прошлого, бывает сложно или даже невозможно. Дело не только в непонимании намеков, апеллирующих к реалиям ушедшей эпохи, но и в изменении социокультурной ситуации, зачастую навязывающей иное толкование увиденного. Это объясняется и тем, что «карикатура - сложный исторический источник, так как представляет собой срез культурной памяти народа с определенным набором культурных кодов, отражает его историческую память и коллективное бессознательное» (Алентьева, 2020, с. 9). Тем не менее обращение к сатирическому образу литераторов рубежа XIX-XX веков позволяет современному зрителю войти в герменевтический круг и увидеть писателя глазами его современников.

Журнальная карикатура, как правило, была адресована среднему (по уровню образования и чаще всего достатка) классу читательской аудитории. Иллюстрированные журналы, где в основном и помещались сатирические рисунки, редко доходили до низовой аудитории и мало пользовались вниманием у наиболее образованной части общества. Известный социолог литературы А.И. Рейтблат утверждал:

«Уровень общей культуры и читательской подготовки представителей "промежуточного" читательского слоя обусловил характер адресованной им издательской продукции. Это был главным образом тонкий иллюстрированный еженедельник универсального характера. В отличие от толстых журналов, содержащих только печатный текст, иллюстрированные журналы сочетали текст с изображением» (Рейтблат, 2009, с. 105).

Учитывая наиболее распространенный читательский адрес иллюстрированных журналов, по колебаниям частотности появления карикатур можно увидеть возрастающую степень известности того или иного писателя. Поскольку литературный канон не может не обновляться, в списке наиболее почитаемых авторов возникают новые имена. Соответственно, появляются и сатирические рисунки, посвященные этим литературным фигурам.

Сердцем отечественного канона русский человек, скорее всего, будет считать А.С. Пушкина. Сатирическая графика рубежа веков вспоминает Пушкина чаще всех писателей прошедшей эпохи, актуализируя с его помощью 
современный Серебряному веку контекст. Н.В. Гоголь встречается не так часто, как Пушкин. Если в юмористическом журнале 1860-х годов «Заноза», например, его лицо изображалось в центре заголовочного комплекса («шапки»), то в начале XX века к нему обращались реже, и чаще в виде уже либо посмертной тени, либо вариации памятника. Еще реже сатирическая и юмористическая периодика начала XX века обращается к образам М.Ю. Лермонтова, Н.А. Некрасова, Ф.М. Достоевского, И.С. Тургенева. По Некрасову и Тургеневу (особенно последнему) карикатур было немало при их жизни и чуть позднее; на Лермонтова и Достоевского сатирических рисунков публиковали значительно меньше. Совсем немного выявлено карикатур на А.П. Чехова. В основном они связаны с чеховской драматургией (прежде всего с пьесами «Чайка» и «Три сестры»). Иногда художники акцентируют внимание на большом количестве публикаций Чехова в толстых журналах. Например, антропоморфная «Русская мысль» умоляет писателя не оставить ее («Московская пресса», 1903, с. 1).

На рубеже веков неслыханная слава Л.Н. Толстого отражается и в лавине карикатур на него. Московский библиограф начала XX века Ю.Ю. Битовт собрал и опубликовал 32 карикатуры на писателя, «Альбом Вольфа» поместил 22 карикатуры (Битовт, 1908; Краснов \& Вольф, 1903). Карандаш карикатуриста поневоле следовал за взлетом литературных репутаций; именно этим можно объяснить и огромное число сатирических рисунков начала XX века на М. Горького. «Можно смело сказать, что ни один из писателей не служил так часто сюжетом для карикатур, как Максим Горький», - утверждал в начале XX века С. Либрович (Русаков, 1903, сс. 7-8). Количество сатирических изображений Горького превышает все традиционные для русского писателя числа в научный оборот введено более 500 карикатур на него, и это далеко не все существующие.

Среди опубликованных на рубеже XIX-XX веков карикатур с образами писателей нам почти не встретились те рисунки, что нарушали общественные запреты, хотя преодоление социальных табу - одна из задач карикатуры. Можно предположить, что это связано с цензурными ограничениями, тем более что в годы слабости или гибели цензуры сатирические рисунки выходили всегда острее. В начале XX века художники соревновались друг с другом в необычной манере изображения модернистов. Представляя модернистов, карикатуристы часто изображали нечеловеческие тонкие руки и ноги, сплетение тел, вакханалию танцев, иногда даже намекая на скотоложество. Многие эти признаки есть в коллективном шарже «Пляска безумства», где восемь литераторов выделывают невообразимые движения («Пляска безумства (шарж)», 1909, с. 15). 


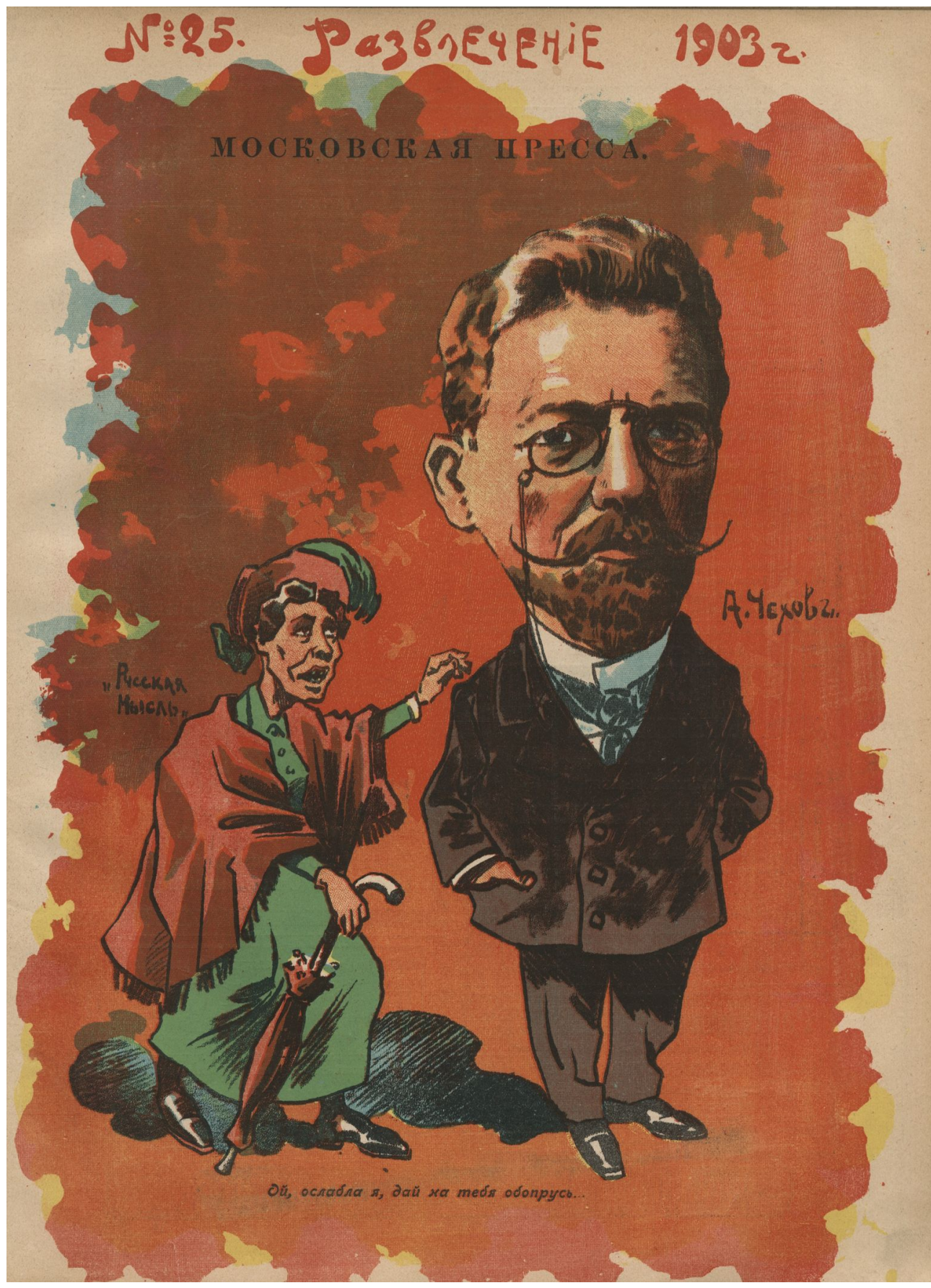

Рисунок 9. Без подписи (1903г). Московская пресса. Развлечение, 25, 1.

Figure 9. unsigned (1903g). Moscow Press. Entertainment, 25, 1. 


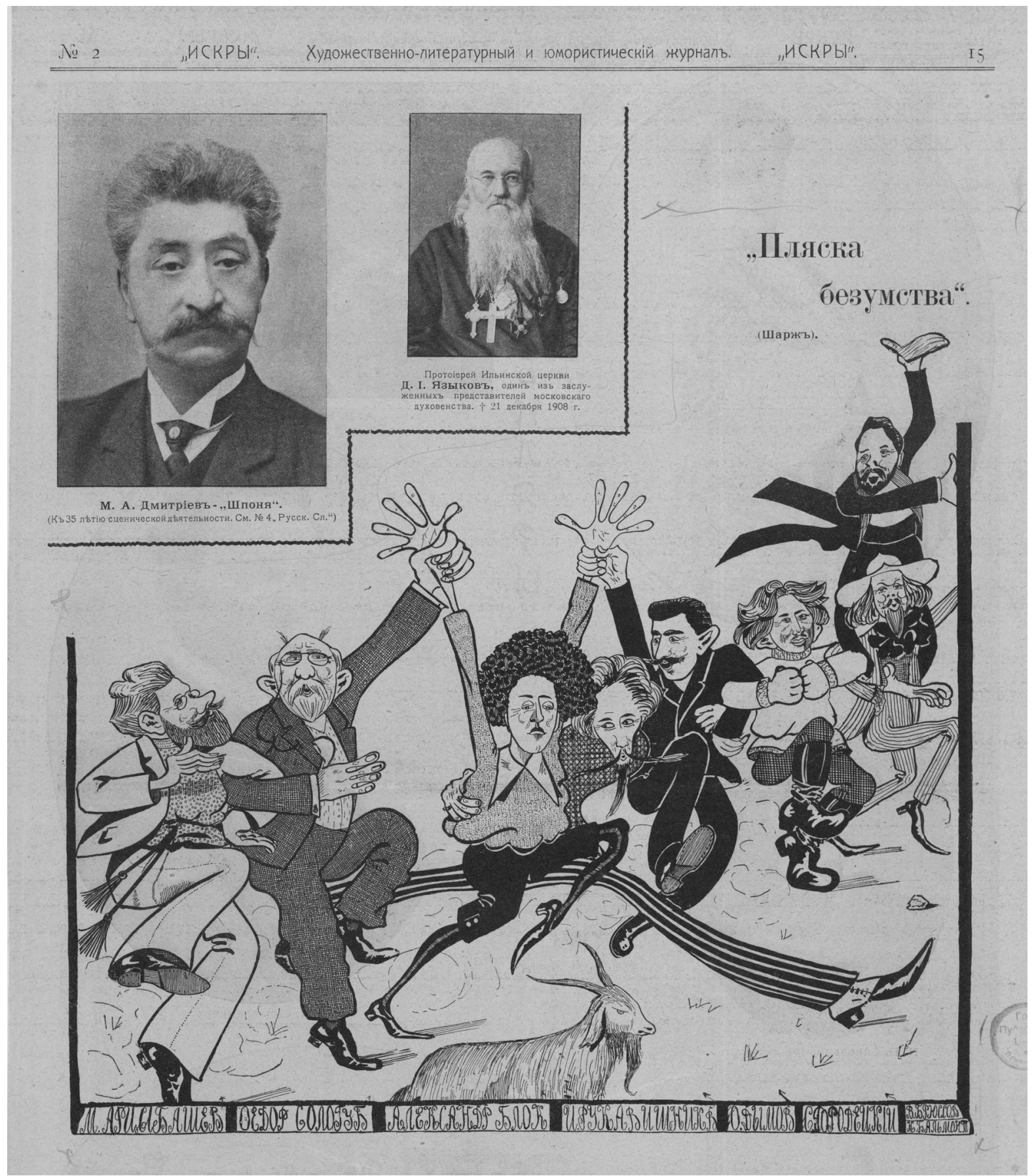

Рисунок 10. Без подписи (1909). Пляска безумства (шарж). Искры, 2, 15.

Figure 10. Unsigned (1909). The Dance of Madness (caricature). Sparks, 2, 15.

На другой карикатуре извиваясь, подобно дымку костра, на фоне темного неба змеятся три прозрачные фигуры: З.Н. Гиппиус, Д.С. Мережковский, А.Л. Волынский («Два духа», 1899, с. 1). Есть и примеры зооморфной графики, когда С.М. Городецкий, Н.А. Клюев, А.М. Ремизов и С.А. Есенин сидят на ветке 
в виде павлина, совы, орла и общипанного воробья с человеческими головами (Праведников, 1915, с. 16).

Подводя итоги, можно сказать, что в карикатурах рубежа XIX-XX веков лидируют три писательских образа: два современника той эпохи (Л.Н. Толстой, М. Горький) и один писатель прошлого (А.С. Пушкин). Воспоминания о литераторах XIX века в сатирических рисунках встречаются редко; карикатуры на модернистов чаще изображают абстрактные, а не конкретные образы (или, возможно, не узнанные нами). Частотность выявленных карикатур, связанных с образом писателя, в целом подтверждает устоявшиеся представления о списке авторов, входящих в русский литературный канон. Так и должно было быть, ведь в целом «карикатуры являются иллюстрацией существовавших в обществе настроений, предрассудков и стереотипов, без этого они не могли быть восприняты и востребованы аудиторией-реципиентом» (Журавлёва, 2008, с. 216).

Преобладание юмора или сатиры в рисунке было напрямую связано с историческим контекстом, цензурными ограничениями, творчеством отдельного писателя, редакционной политикой изданий, позицией карикатуриста. Читатели судили про знаменитых писателей не только по их произведениям, но и по доступным деталям литературного быта, частью которого стала и карикатура. Сатирический рисунок, следуя своей основной функции, гиперболизирует отдельные черты, порой весьма примитивно толкуя сложные литературные и общественные вопросы. Попытки художников и редакций подстроиться под вкусы читательской аудитории или под упрощенные способы провести рисунок через цензурный контроль приводили к отдаленному формированию некоторых литературных мифов вокруг той или иной фигуры крупного автора. Редко, но все же встречались и содержательные, глубокие рисунки, показывающие не только портретное сходство с героем карикатур, но и отражение сущности писательского мировоззрения (хотя это и не является задачей карикатуры).

Традиции обращения сатирической графики к литературным темам живы и доныне. Но современная действительность не вынуждает российского читателя искать в печатном слове выхода своим думам, как это было до революции, поэтому и карикатуры с образами писателей появляются все реже.

\section{Список литературы}

Айнутдинов, А. С. (2010). Карикатура как тип изображения комической интенции в современных российских печатных СМИ (Автореферат диссертации на соискание ученой степени кандидата наук). Уральский государственный университет, Екатеринбург.

Алентьева, Т. В. (2020). Разящее оружие слеха. Алериканская политическая карикатура ХІХ века (1800-1877). Санкт-Петербург: Алетейя.

Без названия (1903). Шуm, 41, 8-9. 
Galactica Media: Journal of Media Studies. 2021. No 3 | ISSN: 2658-7734

От карикатуры до интернет-мема | https://doi.org/10.46539/gmd.v3i3.194

Без названия (1907). Серый волк, 5, 84.

Беллетристы нового века (1903). Шуm, 14, 8-9.

Битовт, Ю. (1908). Граф Л.Н. Толстой в карикатурах и анекдотах. Москва: М.В. Балдин и Ко.

Блюм, Г. (1995). Западный канон. Книги и школа всех времен. Москва: Новое литературное обозрение.

Боб (1908). Конец «юбилейной кампании». Новое время, иллюстрированное приложение, 11515, 11.

Борель, П. Ф. (1863). Концерт в С-дурном тоне (приложение). Заноза, (9).

В Пушкинском сквере (1906). Свободный смех, 14.

В царстве теней (1880). Шут, 21, 1.

Вахненко, Е. Е. (2019). Литературная личность А.М. Ремизова в карикатурах, шаржах, пародиях современников (1906-1916). Филологический класс, (4). doi: 10.26170/FK19-04-22

Великому Шекспиру (1907). Накануне, 2, 24.

Виппер, Б. Р. (1970). Статьи об искусстве. Москва: Искусство.

Волков, А. М. (1868). Новый год в журналистике. Искра, (1).

Далькевич, М. М. (1887). Обе стороны, разом: Он наш, наш, тащите его! Осколки, 5.

Два духа (1899). Развлечение, 8, 1.

Животовский, С. В. (1913). Лекция Бурлюка в Петербурге. Огонек, 45, 13.

Жуковский, Р. (1864). Промышленно-литературное акробатство. Заноза.

Журавлёва, В. И. (2008). Визуализация образа России в США в период первого кризиса в двусторонних отношениях. В Оче-видная история. Проблемы визуальной истории России ХХ столетия. Сборник статей (сс. 214-246). Челябинск: «Каменный пояс».

Иевлев, Н. И. (1863). Бой из-за подписчиков. Заноза, 47.

K LXXV-летнему юбилею графа Л.Н. Толстого. (1903). Стрекоза, 35, 1.

Калабановский, Н. Т. (1909). Всероссийская борьба. Оса, 11.

Калабановский, Н. Т. (1898). В царстве теней. Стрекоза, 36.

Календарь «Стрекозы». Май. (1900). Стрекоза, 2.

Клевенский, М. М. (1918). И.С. Тургенев в карикатурах и пародиях (с рисунками). Голос минувшего, (1-3), 185-218.

Краснов, П. Н. \& Вольф, Л. М. (1903). Граф Лев Толстой, Великий писатель Земли Русской, в портретах, гравюрах, живописи, скульптуре, карикатурах и т.д. Санкт-Петербург: Товарищество М.О. Вольфа.

Лебедев, А. (1917). Иди под мою защиту. Стрекоза, 31,1.

Л.Н. Толстой как современный философ (1905). Стрекоза, 37.

Матюнин, П. П. (1917). Tempora mutantur. Вечернее время, 1.

Мне хотя бы плохонькую подкомиссию... (1908). Сатирикон, 20, 9.

Молок, Ю. А. (2000). Пушкин в 1937 году. Москва: Новое литературное обозрение.

Морозная фантазия (1899). Будильник, 6. 
Московская пресса (1903). Развлечение, 25, 1.

На мель села, голубушка!.. (1879). Шут, (3), 1.

Написав «Милых призраков», я начинаю думать... (1917). Всемирный юмор, 12.

Не противься злу. (1904). Шут, 46, 16.

Невахович, М. Л. (1846). Шествие в храм Славы. Ералащ, 1, 24.

Новейшие литературные «залежи». (1904). Будильник, 9, 5.

О времена, о нравы! (1877). Развлечение, 8.

Орел с места - вороны на место. (1883). Русский сатирический листок, 15.

Печальная неожиданность. (1908). Сатирикон, 20, 3.

Пляска безумства (шарж). (1909). Искры, 2, 15.

Праведников, Е. И. (1915). Краса. Рудин, 1, 16.

Пров Елдырин, мастеровой человек, Пушкина с пьедестала стряхнул, сам встал и стихи сочинил. (1917). Трепач, 13, 16.

Пушкинские дни (1899). Будильник, 18.

Радаков, А. (1909). О скульпторе, который всех слушался. Сатирикон, 24, 12.

Рейтблат, А. (2009). От Бовы к Бальмонту и другие работы по исторической социологии русской литературы. Москва: Новое Литературное Обозрение.

Ремизов, Н. В. (1907). Яснополянский непротивленец. Стрекоза, 40, 9.

Ремизов, Н. В. (1909). Затруднительное положение. Сатирикон, 12, 1.

Ремизов, Н. В. (1910). Чеховские дни. Сатирикон, $4,1$.

Рожон (1917). Горький на мели. Пугач, 15, 5.

Русаков, В. (1903). М. Горъкий в карикатурах и анекдотах. Санкт-Петербург: Товарищество М.О. Вольфа.

Свириденко, М. А. (1903). К 200-летию периодической печати. Развлечение, 1, 1.

Симаков, И. В. (1917). Новые ужасы большевизма. Бич, 36, 16.

Современный писатель (1903). Развлечение, 1, 6.

Спиритический сеанс в Ясной Поляне (1907). Русъ, 1,1.

Сухих, И. Н. (2016). Русский литературный канон XX века: Формирование и функции. Вестник Русской христианской гуманитарной академии, 17(3), 329-336.

Сцена на Мойке (к выселению Охранного отделения) (1907). Русъ, 34.

Тэдди (1917). Автономия в Александринке и скорбные тени. Бинокль, 1,1.

Фидели, Н. И. (1903). Подмаксимовики. Искры, 5, 34.

Фонякова, Н. Н. (1958). Шаржи и карикатуры на И.С. Тургенева. В Описание рукописей и изобразительных материалов Пушкинского дома. Том IV. И.С. Тургенев (сс. 180-207). Москва; Ленинград: АН СССР.

Хлещенко, А. М. (1860). Очерки замечательных литературных деятелей по секрету для публики с натуры. Тетрадъ II. Санкт-Петербург: Литография А.Е. Мюнстера. 
Galactica Media: Journal of Media Studies. 2021. No 3 | ISSN: 2658-7734

От карикатуры до интернет-мема | https://doi.org/10.46539/gmd.v3i3.194

Чемоданов, М. М. (1881). Без названия. Гусли.

Штейн, К. (1900). На злобу дня. Наше время, 5.

Эх, как мозги-то мои почернели (1907). Барабан, 1, 1.

Юнгер, А. (1908). Любовь в отечественной литературе. Сатирикон, 2, 8.

Mersu (1903). Современный читатель. Наше время, (5), 33.

\section{References}

A sorrowful surprise (1908). Satyricon, 20, 3. (In Russian).

Alas, my brain blacked out (1907). The Drum, 1, 1. (In Russian).

Alentyeva, T. V. (2020). The striking blade of laughter. American political cartoons in the 19th century (1800-1877). St. Petersburg: Alteya. (In Russian).

An eagle's domain gets populated by crows if he leaves (1883). Russian Satirical Paper, 15. (In Russian).

Aynutdinov, A. S. (2010). Caricature as a form of expression of comic intentions in modern Russian printed media (PhD thesis abstract). Ural State University, Yekaterinburg. (In Russian).

Bitovt, Yu. (1908). Count Leo Tolstoy in cartoons and jokes. Moscow: M.V. Baldin and Co. (In Russian).

Bloom, H. (1995). The Western canon: The books and school of the ages. Moscow: New Literary Review. (In Russian).

Bob (1908). End of the "anniversary campaign". New Age, Illustrated Supplement, 11515, 11. (In Russian).

Borel, P. F. (1863). Concert in C-bad tone (Supplement). Thorn, (9). (In Russian).

Chemodanov, M. M. (1881). Untitled. The Psaltery. (In Russian).

Dalkevich, M. M. (1887).Both sides at once: He's ours, pull him in! Shards, 5. (In Russian).

Dancing mania (cartoon) (1909). Sparks, 2, 15. (In Russian).

Don't fight evil (1904). Jester, 46, 16. (In Russian).

Dragonfly's calendar. May. (1900). Dragonfly, 2. (In Russian).

Fiction writers of the new age (1903). Jester, 14, 8-9. (In Russian).

Fideli, N. I. (1903). Looking up to Gorky. Sparks, 5, 34. (In Russian).

Fonyakova, N. N. (1958). Cartoons and caricatures of Ivan Turgenev. In Description of manuscripts and visual materials stored by the Pushkin house. Book 4, Ivan Turgenev (pp. 180-207). Moscow; Leningrad: USSR Academy of Sciences. (In Russian).

For the 75th anniversary of count Leo Tolstoy (1903). Dragonfly, 35, 1. (In Russian).

Frosty fantasy. (1899). The Alarm Clock, 6. (In Russian).

Having written "Sweet ghosts" I cannot help but think... (1917). Worldwide Humor, 12. (In Russian).

I'd beg for as little as a subcommission... (1908). Satyricon, 20, 9. (In Russian).

Ievlev, N. I. (1863). Battle over subscribers. Thorn, 47. (In Russian).

In the Pushkin garden (1906). Free Laughter, 14. (In Russian). 
In the realm of shadows (1880). Jester, 21, 1. (In Russian).

Kalabanovsky, N. T. (1898). In the realm of shadows. Dragonfly, 36. (In Russian).

Kalabanovsky, N. T. (1909). All-Russian struggle. Wasp, 11. (In Russian).

Khleschenko, A. M. (1860). Sketches of notable authors secretly drawn from nature. Book II. St. Petersburg: A.E. Munster's Lithography . (In Russian).

Klevensky, M. M. (1918). Ivan Turgenev in caricatures and parodies (illustrated). Voice of the Past, (1-3), 185-218. (In Russian).

Krasnov, P. N., \& Wolf, L. M. (1903). Count Leo Tolstoy - the great Russian author in portraits, etchings, paintings, sculputres, caricatures etc. St. Petersburg: M.O. Wolf's company. (In Russian).

Lebedev, A. (1917). Come under my protection. Dragonfly, 31, 1. (In Russian).

Leo Tolstoy as a modern philosopher (1905). Dragonfly, 37. (In Russian).

Matyunin, P. P. (1917). Tempora mutantur. Evening Times, 1. (In Russian).

Mersu. (1903). Modern reader. Modern Age, (5), 33. (In Russian).

Modern author (1903). Leisure, 1, 6. (In Russian).

Molok, Yu. A. (2000). Pushkin in 1937. Moscow: New Literary Review. (In Russian).

Moscow press (1903). Leisure, 25, 1. (In Russian).

Nevakhovich, M. L. (1846). Procession to the temple of Glory. Yeralash, 1, 24. (In Russian).

Newest literary "deposits" (1904). The Alarm Clock, 9, 5. (In Russian).

Oh how times have changed! (1877). Leisure, 8. (In Russian).

Pravednikov, E. I. (1915). Beauty. Rudin, 1, 16. (In Russian).

Prov Eldyrin the master craftsman unseated Pushkin from his throne, sat on it himself and composed a verse (1917). The Blabbermouth, 13, 16. (In Russian).

Pushkin days (1899). The Alarm Clock, 18. (In Russian).

Radakov, A. (1909). Of the sculptor who listened to everyone. Satyricon, 24, 12. (In Russian).

Ran aground, darling!.. (1879). Jester, (3), 1. (In Russian).

Reitblat, A. I. (2009). From Bova to Balmont and other works on historical sociology of Russian literature. Moscow: New Literary Review. (In Russian).

Remizov, N. V. (1907). The non-resister of Yasnaya Polyana. Dragonfly, 40, 9. (In Russian).

Remizov, N. V. (1909). A most perplexing state. Satyricon, 12, 1. (In Russian).

Remizov, N. V. (1910). Chekhov days. Satyricon, 4, 1. (In Russian).

Rozhon. (1917). Gorky is broke. The Popgun, 15, 5. (In Russian).

Rusakov, V. (1903). Maxim Gorky in cartoons and jokes. St.Petersburg: M.O. Wolf company. (In Russian).

Scene on Moika (for the eviction of the Political police department). (1907). Rus', 34. (In Russian).

Simakov, I. V. (1917). New horrors of Bolshevism. Scourge, 36, 16. (In Russian).

Spirit session in Yasnaya Polyana (1907). Rus', 1, 1. (In Russian).

Stein, K. (1900). Topical. Modern Age, 5. (In Russian). 
Sukhikh, I. N. (2016). Russian literary canon of the 20th century: shaping and functions. Journal of Russian Christian academy of humanities, 17(3), 329-336. (In Russian).

Sviridenko, M. A. (1903). For the 200th anniversary of periodic press. Leisure, 1, 1. (In Russian).

Teddy (1917). Autonomy of the Alexandrinsky theater and the grim shadows. The Binoculars, 1, 1. (In Russian).

To the great Shakespeare (1907). On the Eve, 2, 24. (In Russian).

Two spirits (1899). Leisure, 8, 1. (In Russian).

Untitled. (1903). Jester, 41, 8-9.

Untitled. (1907). Grey Wolf, 5, 84. (In Russian).

Vakhnenko, E. E. (2019). Alexander Remizov's literary personality in caricatures, cartoons and parodies created by his contemporaries (1906-1916). Philological Class, (4). doi: 10.26170/FK19-04-22 (In Russian).

Vipper, B. R. (1970). Articles about art. Moscow: Art. (In Russian).

Volkov, A. M. (1868). New year in journalism. Spark, (1). (In Russian).

Yunger, A. (1908). Love for the national literature. Satyricon, 2, 8. (In Russian).

Zhivotovsky, S. V. (1913). Burliuk's lecture in St.Petersburg. The Light, 45, 13. (In Russian).

Zhukovsky, R. (1864). Literary-Industrial acrobatics. Thorn. (In Russian).

Zhuravleva, V. I. (2008). Picturing the image of Russia from the US during the first crisis in the countries' bilateral relations. In Evi-dent history. Problems of Russian visual history in the $20^{\text {th }}$ century. Digest of articles (pp. 214-246). Chelyabinsk: Stone Belt. (In Russian). 